\title{
Research
}

\section{Landscape Influences on Fisher Success: Adaptation Strategies in Closed and Open Access Fisheries in Southern Chile}

\author{
Tracy Van Holt ${ }^{1,2}$
}

\begin{abstract}
Determinants of fisher success in southern Chile's loco (Concholepas concholepas) fishery are examined by comparing fisher success in exclusive access territories that vary in relationship to tree-plantation development, which can affect shellfish quality. The relative importance of fishers' experience and capture technology (traditional measures of fisher success) are evaluated against environmental and geospatial characteristics. While knowledge and technology explained variation in catches, this did not translate into higher prices or profit. Fishers succeeded (gained higher prices for locos and had higher monthly incomes from their management areas) when they harvested shellfish from closed (exclusive) nearshore management areas where the environmental condition produced high quality locos regardless of their fishing experience, technology, and the geospatial features of management areas. Experienced fishers who worked in management areas near tree plantations that fail to produce resources of sufficient quality shifted to offshore fisheries where their experience counted. Offshore fishers working in the congrio (Genypterus chilensis) fishery likely exposed themselves to more risk and benefited from their experience and available technology; environmental condition and geospatial factors played little role in their success (price). Closed management areas provided resources to harvest, but may reduce a fisher's ability to adapt to environmental change because success depends on environmental factors outside of a fisher's control. Fishers were not financially rewarded for their experience or their technology in the loco fishery.

Key Words: adaptation strategies; Chile; closed-access; Concholepas concholepas; endobionts; experience; fisheries; fisher success; Genypterus chilensis; human environment; landscape change; land-sea interface; traditional ecological knowledge (TEK); tree plantations
\end{abstract}

\section{INTRODUCTION}

\section{Fisher success}

Fishers constantly face uncertainty and adapt their behavior in response to environmental fluctuations and regulations (Salas 2004). Estimates report that $37 \%$ of the Earth's population lives along the coast (within $100 \mathrm{~km}$ of a coastline) (Cohen et al. 2007) and the associated development threatens fisher success and coastal communities. Landscape change and the associated nutrient input into coastal systems directly affect marine community composition (Kemp et al. 2005) and fisheries (Van Holt et al. 2012). Quantifying the factors that affect fisher success, whether defined as catch per unit effort, total catch, price paid per $\mathrm{kg}$ of resource, or profit, can contribute to the identification of which strategies help fishers respond to change. Often fisheries are managed based on ideologies of what factors are perceived to determine success, when in reality these factors may or may not drive success (Durrenberger 1996). This may lead to fisheries management approaches that inadvertently expose fishers to more risk or transform fisheries so that expertise or technology no longer benefits fishers. In this study we ask: (1) Do changes in the landscape translate into environmental conditions that negatively affect fisher success? (2) Are the drivers of success the same across open and exclusive access fisheries? and (3) Does providing exclusive access to management areas (MA) make fishers more vulnerable to environmental change, limit success, and possibly expose fishers to more risk? More than half of the world's population ( 4.5 billion people) worldwide depends on fisheries for protein (15\% or more of their diet) (FAO 2010) and successful fishers and management approaches are needed to support this demand. If success is mainly determined by fisher experience, then additional technical skills may foster success. If fisher success is determined mainly by geospatial factors, then changing the configuration of management areas could foster success. If technology fosters success then increasing fleet size could promote success. If the environmental condition explains the majority of success, then regulating where fishers harvest may prevent fishers from responding to environmental change. Management systems may then need to reorganize to foster fisher success.

Scientists have operationalized success as catch per unit effort (CPUE) and have tested the premise that some fishers were better skippers, that is, catch more fish, than others (e.g., Acheson 1977, Palsson and Durrenberger 1982, Thorlindsson 1988). The skipper effect concept and the relative influence of the variables used in these studies can help to characterize which fisher strategies can help fishers adapt and respond to environmental change. Many skipper effect studies test whether or not experience or skill (the skipper effect) explains catch variation, while controlling for technology (Palsson and Durrenberger 1990); some also measured environmental 
measures and geospatial factors (Acheson 1977). An ideology and observed skipper effect was shown in Acheson's (1977) study, which found that placement of lobster traps depended on skill. Fishers also held an ideology of successful fishers. Thorlindsson (1988) reported an observed and perceived skipper effect in Iceland fisheries. Palsson and Durrenberger report on an ideology of a skipper effect and no observed skipper effect in in Iceland (Palsson and Durrenberger 1982, Durrenberger 1993, 1996). Instead, technology (specifically vessel size) was a major predictor of success. Russell and Alexander (1996) found no ideology of a skipper effect but an observed skipper effect in the purse-seine fishery in the Philippines. No ideology of a skipper effect and no observed skipper effect was found in shrimpers in the Gulf Coast (Durrenberger 1993, 1996).

This study focuses on the following measures of success: the reported price received for the catch for loco (Concholepas concholepas) and congrio (Genypterus chilensis) fisheries, and for the loco fishery, the reported monthly income generated from the management area, total catch, and catch per unit effort were also analyzed. Fisher success in a fishery with exclusive (closed) access (loco) was compared with fisher success in an open access fishery (congrio). The study takes place in a region where nutrient runoff from the landscape directly affects the quality of resources in the closed-access nearshore fishery, and it focuses on the question of when experience counts and when geographic features, the environment, or technology might trump experience. Experience is used as a proxy for traditional ecological knowledge, the expertise that might lie behind the skipper effect. We test whether or not the amount of variance in success is explained by variation in experience and in technology. If experience and technology do not predict success, then what does? In closed-access fisheries, environmental factors may be important predictors of success if fishers cannot move to another location to harvest. Likewise, the geospatial features of the management areas could also predict success since they are related to the resources available, transportation cost, market access, and knowledge, factors that fishers take into account when they are harvesting and marketing resources.

\section{Fisheries management in Chile}

\section{Territorial User Rights Fisheries}

Recently Chile implemented a Territorial User Rights Fisheries (TURF) management system to protect benthic species from overharvesting by providing fishers quasiproperty rights to parcels of the ocean called managed exploitation areas for benthic resources (MEABR) and exclusive rights to the benthic resources in those areas (Bernal et al. 1999, Gelcich et al. 2010). The MEABRs are globally considered an important innovation in fisheries governance although scientists recognize that more resilience can be incorporated into the system (Gelcich et al. 2010) and that providing tenure may leave fishers vulnerable to unanticipated socioeconomic changes (Aswani 1999). One potential affect is that fisheries regulations reduce the influence of fisher knowledge and experience in the fishery. The opposite affect could occur as well where more expertise is required for success and fishers expose themselves to more and more risk to be financially rewarded.

The MEABRs were implemented to control harvest of the loco fishery, a benthic shellfish fishery that collapsed in the mid 1980s. Fishers can legally harvest locos only within their assigned management areas along the coast. As of 2004, most of the usable coast in the study site (Figure 1) was divided into management areas allocated among organized fishing groups. In 2004, fishers in the study area were conducting their first, second, or third harvest under the new management system. Prior to this, there were essentially no locos to legally harvest.

Fig. 1. Study Site in the Valdivia-Province Coastal System, Chile. The management areas are located in black along the coast. In some cases two management areas are listed due to space constraints (i.e., Huape A and Huape B). Watersheds are numbered from 1 to 4 . Some fisher syndicates have more than one management area. The influence of forest plantations (high chlorophyll-a concentration values in the nearshore and loco shellfish with high levels of shell-boring organisms) extends from the outlet of Rio Valdivia (the river from the Valdivian watershed, \#3) northward (management areas Punta Numpulli northward).

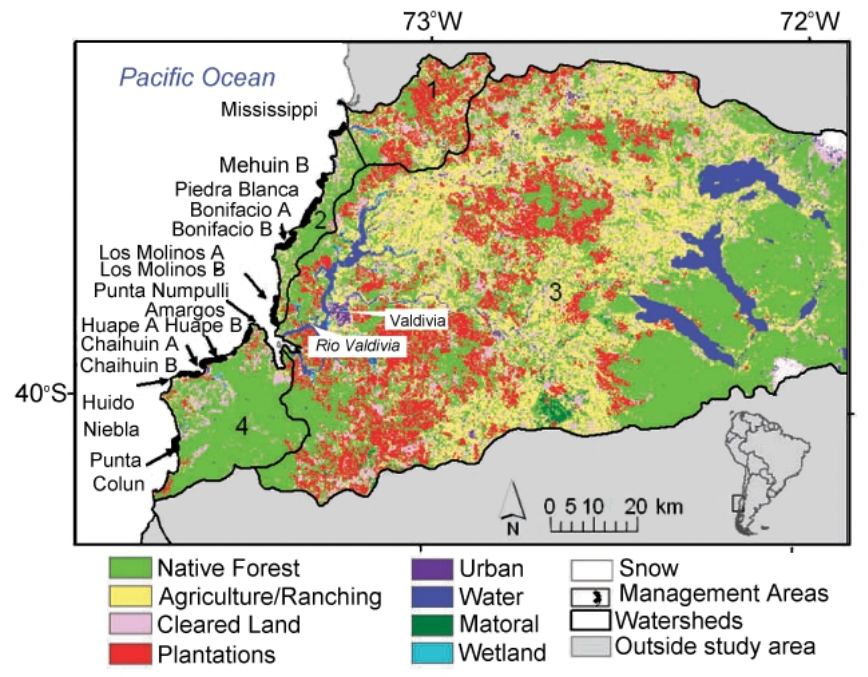

Most fishers belong to fishing syndicates, although fishers can also legally organize as associations or indigenous organizations. Strong kin connections persist within most organizations. Although the TURF system only applies to benthic organisms and the fishery has a very short season, fishers will throw out foreign fishers if they attempt to catch anything in their management area during the year. Fishers 
are not legally restricted on where they can harvest finfish. The rivers are open access and local rules govern river access, although a few legal concession areas also exist. The river concessions are distinct from the MEABRs; no new concessions are granted in the rivers. While some concessions are still productive for mussel harvest, others are not because, according to fishers, mussel development has been truncated because of environmental changes in areas where mussels once were productive. Fishers don't want to give up these coveted areas but owe the government fees for these areas regardless of whether they harvest sufficient resources to pay the fee.

Four types of artisanal fishers exist: (1) purse seine fishers who harvest fish offshore (up to two degrees latitude offshore) in medium-sized boats (up to $18 \mathrm{~m}$ ) (Canales et al. 2008); (2) divers who use hookah equipment and small motorized boats (7.4 $\mathrm{m}$ average) to harvest benthic resources in rivers and in the nearshore; (3) coastal fishers that operate small motorized or sail-powered boats (7.4 m average) and long line hooks or cast nets to catch fish nearshore and offshore; and (4) collectors of nearshore resources who walk along the tidal interface and harvest kelp and other accessible resources. The purse seine fishers do not have management areas and only work in the open ocean. Benthic fishers, coastal fishers, and coastalresource collectors harvest locos because they fetch a high price for locos relative to other fisheries and because the management areas are usually located close to home. Some fishers harvest locos during the harvest season and do not work in other fisheries during the rest of the year while others work in fisheries year round. Offshore fishing is considered riskier than working in the loco fishery. During the year of this study, three coastal fishers died when they were fishing offshore in a storm and their small boat capsized. Diving can also be dangerous when fishers expose themselves to greater depths and time under water. Some fishers have physical handicaps as a consequence of diving accidents. Fisher experience

Although there are experts and novices within each syndicate, new commercial fishers were often located in more remote areas, while traditional commercial fishers were located closer to population centers and areas with environmental change. When the MEABRs were established, each syndicate solicited a management area. The people living closest to the MA had priority. Because new fishers were introduced to the system when the management areas became established, the amount of time that fishers spend in the open ocean, the rivers, and management areas, as well the species fished, alternative livelihood strategies, and the amount of land owned separate many novice from experienced fishers. When the MEABRs were established, essentially anyone who was a certified diver, fisher, or a collector of onshore resources could join a fisher organization and solicit a management area from the Servicio Nacional de Pesca (SERNAPESCA). Before the MEABRs, commercial fishers consisted mainly of people dependent on fisheries as their sole source of income and few had additional land for terrestrially-based agricultural activities. Today commercial fishers include new fishers who also have land for agriculturally-based activities. People were attracted to government assistance and the potential to earn money from the coast and as a result, many new people entered the fishery. The newer, part-time fishers harvest mainly management area locos. When the year's going prices for locos are low, these part-timers stay on shore, participate in terrestrially-based activities, and await better prices the following year when locos are larger. In contrast, full-time fishers with more fishing skills, technology, and marketing experience capture species in addition to locos. More experienced fishers spend more time offshore and harvest multiple species of finfish and benthic organisms; they also dive and fish in the local rivers. Those who depend entirely on fishing and have traditionally fished marine resources with boats and have better fishing knowledge and organizational skills cannot always wait for a better loco price because they are completely reliant on the fisheries. More experienced fishers may also expose themselves to more risk because the financial payoff may be higher. Bernard (1967) showed that Greek sponge divers often risked their safety to make more money and prove themselves as experts. Johnson and Orbach (1990) showed that experienced fishers exposed themselves to more risk when they placed lobster traps offshore where the weather and wind patterns were less predictable and storms could destroy traps, but the financial payoff is higher. Novices did not participate in offshore lobster fishing. The harvest

On average, in management areas across administrative regions $\mathrm{X}$ and XIV, which were grouped together and called region $X$ prior to 2007, artisanal fishers harvested 3,278 tons of locos, a benthic gastropod, each year between 2003 and 2005. The loco harvest occurs from April to August, with the majority of the harvest taking place over about ten days in July and August (Servicio Nacional de Pesca 2003, 2004, 2005). If fishers harvest another species in management areas, they usually harvest lapa (Fissurella species) at a small scale; however, people usually do not harvest other benthic species because the loco is a carnivore and fishers want to make sure that locos have adequate food. Fishers also have to pay consultants for the survey of other benthic species and often the amount of money they make from other harvests does not warrant the expense.

Locos are substitutes for abalone in global markets and the majority of the locos are exported globally. Country-wide prices are affected by global markets, but regional price differences depend mainly on loco quality. Supply and demand have less influence over the fishery regionally because information on the harvest quotas for management areas is publically available and buyers know the approximate annual harvest. This is distinct from fisheries in the U.S. (Hatteras, North Carolina) where fishers return home in the middle of a 
harvest event because prices have dropped in a matter of hours (Van Holt, personal observation). Harvesting locos in the management areas is a group effort, in which the president of each syndicate processes the legal paper work and organizes the group. The transportation records of locos provide approximate catch per unit effort data at the syndicate level since loco buyers will not purchase locos that have been aposado or sitting around. Locos cannot be aposado for more than a day or they show signs of distress. For example, if locos are sitting around near brackish water where many of the ports are, they become bloated and then buyers refuse to buy the batch. Some fishers could still attempt to group locos together and sell two days' worth of locos at the same time so catch per unit effort data provided by the government may have this flaw. For many fishers locos are their primary source of income even though they may participate in other fisheries or agriculture. An individual's pay depends on the syndicate's rules; some syndicates divide the money equally and others give divers more money.

Most syndicate presidents in the Valdivian region face enormous pressure to harvest entire quotas (Van Holt, personal observation). Gelcich et al's (2007) study of fisher harvest decisions showed that divers (the more experienced fishers) would reportedly withhold harvest given a low price. The fishers in that study, however, have the best quality locos regionally and receive top prices for their locos (Van Holt 2009). In contrast fishers from the Valdivian region have lower quality locos (Van Holt 2009), and experienced fishers, especially those syndicates with low quality locos, usually harvest the entire quota despite low prices.

For those who are not making enough money on management area loco, congrio colorado (Genypterus chilensis), a finfish species, is an alternative. In administrative region X and XIV, 346 tons of congrio colorado finfish were annually caught from 2003 to 2005 (Servicio Nacional de Pesca 2003, 2004, 2005). Small groups of fishers harvest congrio close to home but outside of any management areas (usually half a $\mathrm{km}$ from the coast or beyond). Congrio colorado live from the continental shelf up to $400 \mathrm{~m}$ depths; they consume mainly crustaceans as well as fish and mollusks (Chong et al. 2006). The congrio colorado harvest peaks from October to February although the fish is harvested year-round. The market and price for congrio colorado reflects the local market and is stable.

\section{Operationalizing success}

Experience and technology

A fisher's experience has been measured in several ways, including by age (Palsson and Durrenberger 1982); by correlating a skipper's catches over subsequent years to see if the same skippers consistently succeed (Thorlindsson 1998); as the unexplained variance in fisher success models (Bjarnason and Thorlindsson 1993); mean catch per trip by boat; and the number of crew (Russell and Alexander 1996).
However it has been measured, experience helps people successfully respond to ecological surprises and manage and harvest resources (Berkes et al. 2000). In this study, experience is measured by where fishers work, what they fish, how long they have fished, alternative livelihoods, education, and land owned. Technology typically has been measured as boat size (Palsson and Durrenburger 1982, Thorlindsson 1988), and gear type (Hilborn and Ledbetter 1985). Individual boat ownership may be less important in developing country fisheries, such as those in the Philippines (Russell and Alexander 1996) or those in Chile, where regulations are tied to groups of fishers, and people can harvest in teams. In the Chilean fisheries, there was little variance in boat size since artisanal boats ranged from $5 \mathrm{~m}$ to $18 \mathrm{~m}$ and had similar sized motors. Boat power in each syndicate, however, is more indicative of success because one syndicate can have four boats and another syndicate can triple that amount. Consequently, in this study technology is measured by the number of boats in each fishing syndicate. Environment

In skipper effect studies, few have quantified environmental variance (but see Acheson 1977). For fishers who harvest nearshore in Chile, the quality of local resources varies by upland land use, and land-use variables are potential predictors of success for the loco fishery.

Many nearshore systems are becoming more eutrophic from landscape change that includes agriculture, deforestation, plantation development, animal production, and urbanization activities that fertilize the soils and increase nutrient loading and sediment delivery to the rivers (Nixon 1995). Nutrient enrichment causes changes in photosynthetic biomass that leads to phytoplankton blooms that in turn decrease light penetration and oxygen levels in the nearshore (Smith et al. 1999, Kemp et al. 2005). Since phytoplankton (Ware and Thomson 2005) and predators structure marine systems (Verity and Smetacek 1996), changes in photosynthetic biomass alter benthic marine communities and food webs (Diaz and Rosenberg 1995, Kemp et al. 2005). Consequently, organisms may be more susceptible to endobionts (shellboring organisms) or epibionts (organisms that live on top of the shell) (Zander and Reimer 2002, Van Holt et al. 2012).

In Chile, pine (Pinus radiata) was introduced in the 1940s to protect degraded riparian areas (Lara and Veblen 1993). To bring Chile into the world market economy and to make the country less vulnerable to the fluctuations in the copper market (Auty 1993, Gwynne 1996), the government subsidized indemand, nontraditional agricultural exports such as pine trees. Plantation development exploded when the Pinochet administration subsidized $75 \%$ of the cost of plantation establishment, and eucalyptus (Eucalyptus globulus and Eucalyptus nitens) became an important pulp species (Lara and Veblen 1993). By 1992, Chile was the world's sixth most important wood pulp exporting country (Sedjo 1999). Van Holt et al. (2012) have shown that loco shellfish located near 
tree plantations have more epibionts and endobionts and that chlorophyll-a, a proxy for photosynthetic biomass, is also higher in regions closer to landscape change. While it is unlikely that the congrio fishery is affected by the epibionts and endobionts on the locos, congrio may be associated with chlorophyll-a because these characteristics may indicate congrio food sources. Geospatial features

Fishers decide when, where, what, and how much they harvest based, in part, on geospatial features of where they live and fish (Aswani 1998, Shester 2010), although regulations can also influence where fishers harvest (Gelcich et al. 2006). The species harvested depends on market proximity (Cinner and McClanahan 2006) and travel costs (Sampson 1994, Aswani 1998). Fisher decisions also depend on the quality of the harvest area and how much energy they need to spend reaching it (Guest 2003). In Chile, since fishers are now geospatially restricted, for the highly valuable loco fishery, success could depend, in part, on how far fishers are located from their management areas since areas along the Chilean coast are still not developed with roads, and buyers cannot always reach remote areas. Likewise not all fishers have developed ports or live close to their port, and these distance measures may factor into the price that fishers may be paid for a resource. Fishers with larger management areas may have to invest more time managing and guarding their resources, leaving less time for other activities.

\section{METHODS}

\section{Research design}

The environmental variation of loco quality, tree plantations, and chlorophyll-a patterns in the system makes for a natural experiment (space-for-time substitution) to test the relative influence of the landscape change and associated environmental factors on fisher success. The Valdivian province of Chile contains four large watersheds, named after the main river in the watershed: Lingue (1), Bonifacio (2), Valdivia (3), and Chaihuín (4), which are all contained in the administrative region XIV (Figure 1). The influence of plantations in the nearshore environment varies by zone instead of watershed. Zone 1 is the region near watersheds 1-3, where extensive plantation development $\left(1,415 \mathrm{~km}^{2}\right)$ occurred from 1985 to 2001 . Zone 2 is the region near watershed 4 , where few plantations $\left(27 \mathrm{~km}^{2}\right)$ were established. Tree plantations are fertilized (Schlatter 1977, Guerra et al. 2007), resulting in increased nitrogen levels in tree plantation watersheds (Oyarzun et al. 2007, Little et al. 2008). Consequently, in zone 1, management areas have higher photosynthetic activity (chlorophyll-a concentration values) across all months between 1998 and 2005 (Van Holt 2009), in comparison with zone 2 . The amount of endobionts on loco shellfish in zone 1 has an average of $30 \%$ of the shell covered with phoronids (Phoronis species) and polychaetes (Class Polychaeta); locos in zone 2 have about 5\% cover (Van Holt et al. 2012). Zone 1 locos also weigh less (Van Holt et al. 2012). Plantation tree percent and total cover in watersheds associated with management areas and chlorophyll-a patterns within the management areas are linked to epibiont and endobiont patterns, especially phoronid, barnacle, and polychaete infestations (Van Holt et al. 2012).

No open access loco fishery in Chile exists and no closedaccess congrio fishery exists in Chile so it is not possible to compare access issues within the same fishery under different regulatory conditions. To evaluate the influence of closed or open access on success, the loco and congrio fisheries were compared. In both fisheries regional prices are shielded somewhat from supply and demand and both fisheries are among the most important for artisanal fishers.

A team that included employees of Proyecto de Fomento (PROFO) Cerqueros, students from Universidad Austral, and the author interviewed 279 fishers from 11 fishing syndicates for the first Fisher Census from the Federación Provincial de Pescadores Artesanales del Sur (FIPASUR); the data were deposited in FIPASUR in Valdivia, Chile. The individuallevel data were obtained through personal interviews and the syndicate-level data were obtained from SERNAPESCA.

\section{Independent variables}

Experience

In developing regions fisher experience may depend on whether fishers own or have access to additional land. If fishers have additional land, they may participate in other livelihood activities, such as agriculture, which influences experience: the species they fish, the type of fisheries in which they work, where they fish, how long they fish, and how long they remained in school (Table 1; Figure 2, blue boxes). Fishers reported on how much land they owned (LAND). Fishers also reported on the number of other fisheries activities (FAC) in which they participated, which include purse seine, diving, and fishing, and on the number of other livelihood activities (OAC) in which they were involved, including tourism, raising domestic animals, agriculture, forestry, and commercialization of products. Fishers then identified the species they harvested from a picture-list of 43 resources. The number of benthic invertebrates (BENT) and fish (FISH) each fisher harvested was calculated. Fishers reported on how many years they had fished (YEAR) and how they distributed fishing effort across the management areas (MAT), open ocean (OCT), and rivers (RIVT). Fishers also reported on how long they studied in school (EDU) to control for educational effects.

\section{Environment}

Tree plantation development is positively related to photosynthetic biomass (chlorophyll-a concentration in the ocean), which is related to loco shellfish quality, that is, length, weight, and presence of endobionts (Van Holt et al. 2012) (Table 1; Figure 2, green boxes). If chlorophyll-a concentration is higher than $2.4 \mathrm{mg} \mathrm{m}^{-3}$, locos contain 
Table 1. Dependent and independent variables tested in this study.

\begin{tabular}{|c|c|c|c|c|}
\hline Factor & Variable & Measure & Method & Code \\
\hline \multicolumn{5}{|c|}{ Independent variables } \\
\hline \multirow[t]{11}{*}{ Experience } & Benthic species harvested & \# of benthic species harvested & interview & BEN \\
\hline & Fish harvested & \# of species of fish harvested & interview & FISH \\
\hline & Management area time & Proportion of time spent in MA & interview & MAT \\
\hline & Open ocean time & Proportion of time spent in ocean & interview & OCT \\
\hline & River time & Proportion of time spent in river & interview & RIVT \\
\hline & Livelihood & $\begin{array}{l}\text { \# of fishing activities (purse seine, } \\
\text { diving, fishing) }\end{array}$ & interview & FAC \\
\hline & Livelihood & \# of activities outside the fishery & interview & $\mathrm{OAC}$ \\
\hline & Land owned & Area of land owned $\left(\mathrm{m}^{2}\right)$ & interview & LAND \\
\hline & Fisher experience & \# of years fishing & interview & YEAR \\
\hline & Years of education & Years of education & Interview & EDU \\
\hline & Fisher age & Age & Interview & AGE \\
\hline \multirow[t]{4}{*}{ Environment } & Carnivore health & $\%$ Loco shell w/ endobionts & ecological survey & BORE \\
\hline & Carnivore health & Weight loco meat (g) & ecological survey & WEIGH \\
\hline & Carnivore health & Length loco meat $(\mathrm{cm})$ & ecological survey & LENGTH \\
\hline & Chlorophyll-a & $\begin{array}{l}\text { Change in chlorophyll-a }\left(\mathrm{mg} / \mathrm{m}^{3}\right) \text { in } \\
\text { management area }(1999-2003)\end{array}$ & satellite image & PHOT \\
\hline \multirow[t]{5}{*}{ Geospatial } & Distance to headquarters & Distance to fisher headquarters & interview & DISTHQ \\
\hline & Size MA & Size (ha) of management area & GIS & AREAMA \\
\hline & Distance to MA & Distance to management area (m) & GIS & DISTMA \\
\hline & Distance to market & $\begin{array}{l}\text { Distance }(\mathrm{km}) \text { from fishing headquarters } \\
\text { to Valdivia city }\end{array}$ & GIS & ROADV \\
\hline & Conversion to plantations & $\%$ new plantation in watershed & satellite image & PLANT \\
\hline Technology & Boat availability & Boats (\#) & interview & BOAT \\
\hline \multicolumn{5}{|c|}{ Dependent Variables } \\
\hline & Total catch & $\begin{array}{l}\text { \# locos caught in the } 2004 \text { season per } \\
\text { syndicate }\end{array}$ & SERNAPESCA & TOTAL \\
\hline & Catch-per-unit effort locos & \# locos/day per syndicate in 2004 & SERNAPESCA & CPUE \\
\hline & Price of loco & Price per kilo (pesos/kg) & Interview & loco \\
\hline & Management area income & $\begin{array}{l}\text { Rank order of income per month in } \\
\text { management area }\end{array}$ & Interview & MAI \\
\hline & Price of congrio & Price per kilo (pesos/kg) & Interview & congrio \\
\hline
\end{tabular}

endobionts and the meat weighs less (Van Holt et al. 2012). An October 5, 1985 Landsat 5TM and a November 29, 2001 Landsat 7 ETM+ scene were classified (WRSII path 233, row 87-89) for changes in native forest, plantation trees, mattoral (shrubland), agriculture, cleared land, wetland, water, and snow classes (Van Holt 2009) and calculated the percent of new plantations in the watershed (PLANT). Average chlorophyll-a concentrations were calculated from April, May, June, and July from 1999 to 2003 in each watershed using the Giovanni program (Acker and Leptouk 2007) that processes SeaWiFS satellite images (9 $\mathrm{km}$ resolution) (Van Holt 2009). Thirty locos were collected by fishers in each of the 11 management areas. The percentage of endobionts (BORE) (phoronids and polychaetes) was recorded (Van Holt et al. 2012). Loco meat was also weighed (WEIGH) and loco length was recorded (LENGTH). Technology
To measure available technology (BOAT), the number of boats that registered with Servicio Nacional de Pesca for each syndicate was totaled and the registration records were verified with fishers (Table 1; Figure 2, orange box). Each fisher in the same syndicate had the same value for boat availability. Individuals also reported on boat ownership but preliminary analysis of these data showed that boat availability was a better predictor of success than individual boat ownership because many active fishers do not own their own boat. Geospatial features

Geospatial factors dictate when a fisher returns to port, harvests more products, or sells a product. Informants reported how far they traveled from their home to the fishing headquarters (DISTHQ) where the boats are moored (Table 1; Figure 2, purple boxes). The distance from the fishing headquarters to the center of the management area (DISTMA) 
Fig. 2. Conceptual framework for how technology, experience, and environmental and geospatial factors influence fisher success.

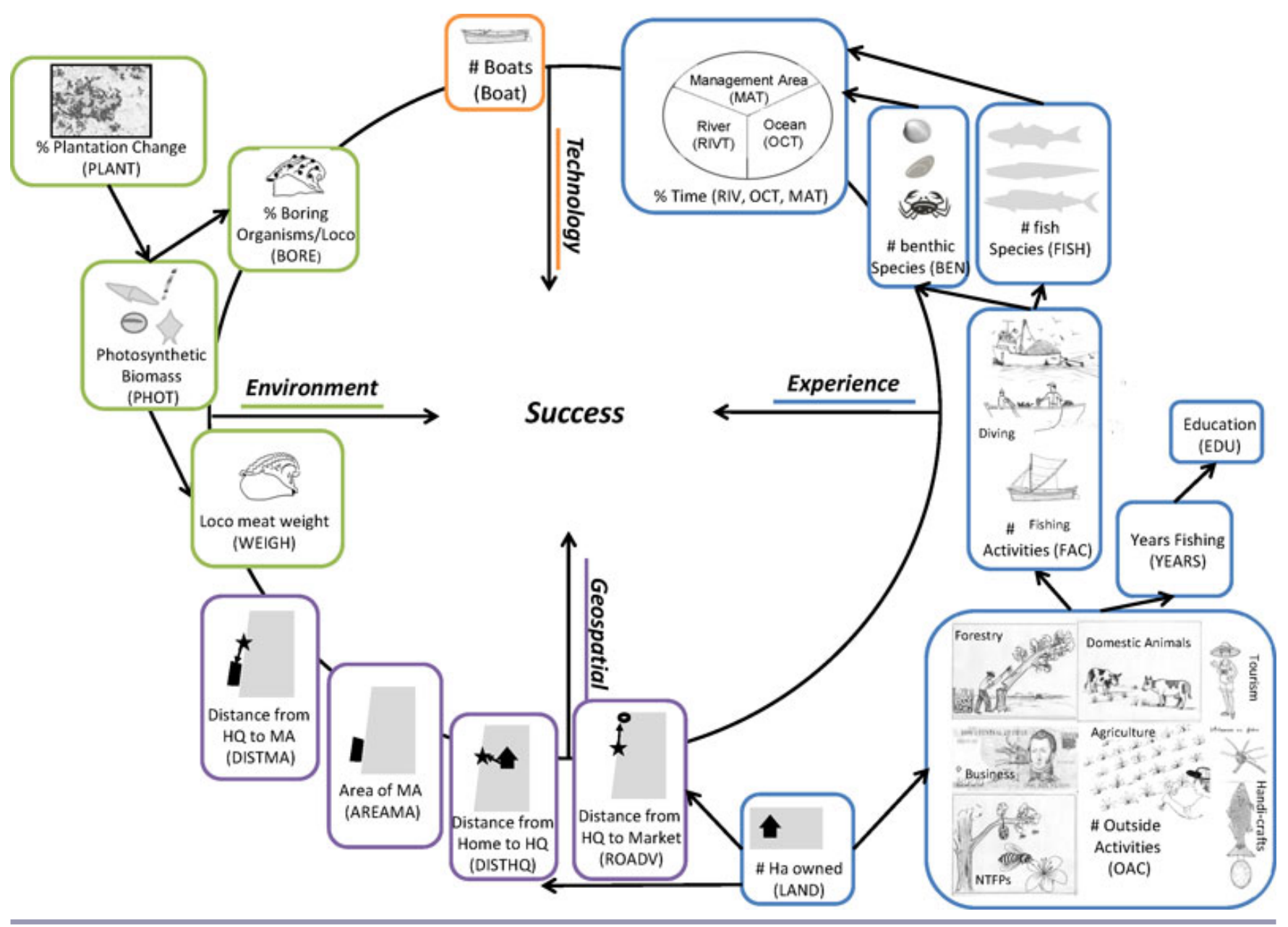

was calculated (ArcGIS 9.0 $0^{\mathrm{TM}}$ ). The distance $(\mathrm{km})$ from the fishing headquarters to Valdivia, the nearest city (ROADV) was also measured. The area of the management area (AREMA) was calculated by digitizing management areas using published coordinates from the Diario Oficial of Chile.

\section{Dependent variables}

Five separate dependent variables were tested: (1) the total catch of locos by the syndicate in the 2004 harvest season (TOTAL); (2) the number of locos harvested per day by the syndicate for the 2004 loco harvest (Catch per Unit Effort, or CPUE); (3) the price each fisher reported receiving for one kilogram of loco; (4) the price each fisher reported receiving for one kilogram of congrio; and (5) the total monthly income (profit) each fisher reported from the management area income (MAI) (Table 1; Figure 2, center). Since fishers provided the price for their top five resources harvested, not all informants were included in the individual-scale analysis (loco $[\mathrm{N}=108]$ and congrio $[\mathrm{N}=74])$.

\section{Analysis}

For the syndicate-level analysis (catch-per-unit effort and total catch), a stepwise regression was run. Since the degrees of freedom were low, specific variables to use were selected and separate environmental, experience-technology, and geospatial models had to be created. For the individual-fisher analysis, dependent variables, loco, congrio, and management-area income, a stepwise multiple regression for independent variables was run (Table 1; Figure 2). The following multicollinear independent variables were first tested for and removed: PLANT, WEIGH, YEAR, and DISTMA. All models for syndicate and individual-level analyses were compared using, in this order, Mallows' $C_{p}$ statistic, the Bayesian information criterion (BIC), a scree plot of mean square error (MSE) vs. model size, and $\mathrm{R}^{2}$ (Mallows 1973, Spiegelhalter et al. 2002). The average price for a kilogram of loco (\$7.20) was used to solve the loco regression model. For the independent variables, the averages of FISH, OCT, and RIVT were obtained from data for all fishers (Appendix 1). 
Fisher-syndicate averages were used for BOAT, BORE, and PHOT variables since the syndicate-level average was used in the individual analysis for these variables (Appendix 2). For the congrio model, average values for all fishers were used for FISH, RIVT, YEARS, and EDU (Appendix 1). An exchange rate of $\$ 1 \mathrm{USD}=600$ pesos was used for loco and congrio equations. To confirm the regression findings with an alternative analysis, a stepwise discriminant analysis was run (PROC STEPDISC in SAS 2001) on groups of successful and unsuccessful individuals. Informants were divided into two groups: those with median prices and above for their catches were considered successful and those with prices below the median were not successful. Finally, correlations were run (with the Bonferroni correction) between management area environmental variables (PHOT and BORE) and experience to test whether where fishers spend their time (MAT, OCT, and RIVT) and what they harvest (BEN and FISH) was tied to the environmental condition of the management areas.

\section{RESULTS}

\section{Closed-access loco}

Geospatial factors, that is, distance from the management area to the port and distance from the port to the market, explained the largest fraction of CPUE (Table 2; Figure 3; Appendix 3). Increased photosynthetic biomass in the management area (environment) positively influences CPUE (Table 3; Appendix 3). Also, fishers who spent more time working in the rivers, less time in the open ocean (experience), and those with more available boats (technology) had higher CPUE (Table 4; Appendix 3). Total catch of locos was explained by experience. Fishers with more experience working in the management areas, open ocean, and rivers gained an advantage and caught more locos (Table 4; Appendix 3).

Table 2. Regression models of catch-per-unit effort (CPUE) for geospatial models. Independent variables used in the analysis shown in column 1 .

\begin{tabular}{ccc}
\hline \hline $\begin{array}{c}\text { Independent } \\
\text { Variables }\end{array}$ & $\begin{array}{c}\text { CPUE Geospatial } \\
(B) \\
\text { Locos/day }\end{array}$ & $\begin{array}{c}\text { CPUE Geospatial } \\
(\mathrm{F})\end{array}$ \\
\hline $\mathrm{R}^{2}$ & $0.75^{* *}$ & \\
Intercept & 923.07 & 0.04 \\
DISTMA & $607.30^{* *}$ & 23.86 \\
ROADV & $79.28+$ & 3.57 \\
DISTHQ & n.s. & \\
$\mathrm{N}$ & 11 & \\
Unit of analysis & Syndicate & \\
\hline
\end{tabular}

Note: $* *$ is highly significant where $\mathrm{p}<0.01, *$ is significant where $\mathrm{p}<0.05,+$ is slightly significant where $\mathrm{p}$ $<0.1$, and n.s. is not significant.
Table 3. Regression models of catch-per-unit effort (CPUE) for environmental models. The environmental model included loco shell-boring organisms, chlorophyll-a concentration in the management area, and loco weight.

\begin{tabular}{ccc}
\hline \hline $\begin{array}{c}\text { Independent } \\
\text { Variables }\end{array}$ & $\begin{array}{c}\text { CPUE Environment } \\
(B) \text { Locos/day }\end{array}$ & $\begin{array}{c}\text { CPUE Environment } \\
(\mathrm{F})\end{array}$ \\
\hline $\mathrm{R}^{2}$ & 0.50 & \\
Intercept & $50339^{*}$ & 16.68 \\
BORE & $\mathrm{n} . \mathrm{s}$ & \\
PHOT & $-16212^{*}$ & 9.13 \\
WEIGH & $\mathrm{n} . \mathrm{s}$ & \\
$\mathrm{N}$ & 11 & \\
unit of analysis & Syndicate & \\
\hline
\end{tabular}

Note: $* *$ is highly significant where $\mathrm{p}<0.01, *$ is significant where $\mathrm{p}<0.05,+$ is slightly significant where $\mathrm{p}<0.1$, and n.s. is not significant.

Table 4. Experience-technology regression models of total locos caught in the 2003 season (TOTAL) and catch-per-unit effort (CPUE). Independent variables used in the analysis include: proportion of time spent in the management areas (MAT), ocean (OCT), the river (RIVT), as well as total number of boats (BOAT).

\begin{tabular}{ccccc}
\hline \hline $\begin{array}{c}\text { Independent } \\
\text { Variables }\end{array}$ & $\begin{array}{c}\text { Total Catch } \\
\text { Experience } \\
(B)\end{array}$ & $\begin{array}{c}\text { Total Catch } \\
\text { Experience } \\
\text { \# of locos }\end{array}$ & $\begin{array}{c}\text { CPUE } \\
\text { Experience } \\
(B)\end{array}$ & $\begin{array}{c}\text { CPUE } \\
\text { Experience } \\
(\mathrm{F})\end{array}$ \\
\hline $\mathrm{R}^{2}$ & 0.82 & & 0.88 & \\
Intercept & $-507267^{* *}$ & 16.05 & $19250^{*}$ & 11.63 \\
$\mathrm{MAT}$ & $6660^{* *}$ & 22.09 & $\mathrm{n} . \mathrm{s}$. & \\
OCT & $4963^{* *}$ & 14.55 & $-335^{*}$ & 10.07 \\
$\mathrm{RIVT}$ & $5354^{* *}$ & 27.22 & $211+$ & 4.55 \\
BOAT & n.s. & & $612^{*}$ & 7.51 \\
$\mathrm{~N}$ & 11 & & 11 & \\
Unit of & Syndicate & & Syndicate & \\
analysis & & & & \\
\hline
\end{tabular}

Note: $* *$ is highly significant where $\mathrm{p}<0.01, *$ is significant where $p<0.05,+$ is slightly significant where $p<0.1$, and n.s. is not significant. 
Fig. 3. Significant causal factors identified in regression (positive influence $[+R]$ and negative influence $[-R]$ ) and discriminate (positive influence $[+D]$ and negative influence $[-D]$ ) analysis. Factors outlined in black were most influential in the (A) loco CPUE (geospatial); (B) loco price (environment); (C) management area income (environment); and (D) congrio price (experience).
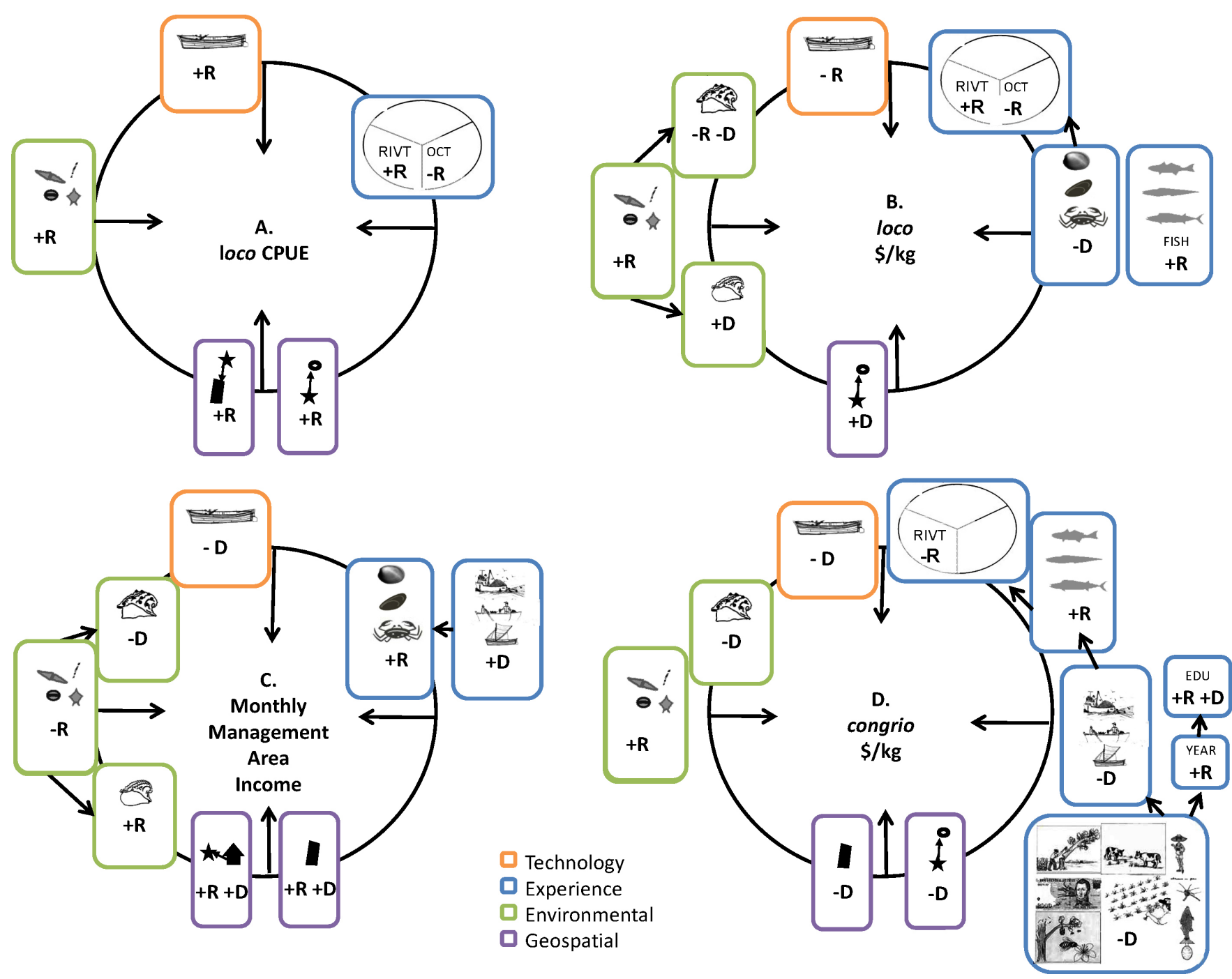

For loco price, the environment explained $64 \%$ of the variance in price. Shell-boring organisms alone explained $43 \%$ of the variance and chlorophyll-a concentration explained another 21\% (Table 5; Figures 3 and 4; Appendix 3). Lack of boats (technology) explained an additional $5 \%$ in the model. Experience explained only $6 \%$ of the price variance; if fishers harvested multiple fish species, spent a large fraction of their time in rivers, and a small fraction of their time in the open ocean, they reported higher prices for locos. Geospatial features were not influential.

A ten-percent increase in endobionts had a dramatic effect and decreased loco price per kilo by $\$ 0.99$ or $17 \%$. A $0.2 \mathrm{mg} / \mathrm{m}^{3}$ increase in chlorophyll-a concentration in the management area increased price per kilo by $\$ 0.28$. It is unrealistic to completely compensate for a $10 \%$ increase in endobionts by reducing fleet size since each syndicate would need to have fewer than four boats (current average is 16 boats per syndicate). Modifying fisher experience is also unfeasible since the loco price increases only $\$ 0.05$ for each additional fish species harvested by an individual, spending $10 \%$ more time working in river-based fisheries adds only $\$ 0.09$, and spending $10 \%$ less time working in the open ocean fisheries adds only $\$ 0.11$ per $\mathrm{kg}$. This still falls short, making up only $25 \%$ of the price decrease from endobionts. 
Table 5. Regression models of loco price (pesos/kg), congrio price (pesos/kg), and monthly income (pesos/mo) in the 2003 season. Only significant independent variables used in the analysis are shown in column 1 (see Table 1 for full list of independent variables).

\begin{tabular}{|c|c|c|c|c|c|c|c|}
\hline Factor & $\begin{array}{c}\text { Independent } \\
\text { Variables }\end{array}$ & $\begin{array}{l}\operatorname{Loco}(B) \\
\text { pesos/kg }\end{array}$ & $\operatorname{Loco}(\mathrm{F})$ & $\begin{array}{c}\text { Congrio }(B) \\
\text { pesos/kg }\end{array}$ & Congrio $(\mathrm{F})$ & $\begin{array}{c}\text { Management } \\
\text { Area Income }(B) \\
\text { Units } \\
\end{array}$ & $\begin{array}{c}\text { Management } \\
\text { Area Income }(\mathrm{F}) \\
\text { Units } \\
\end{array}$ \\
\hline & $\mathrm{R}^{2}$ & 0.75 & & 0.45 & & 0.35 & \\
\hline & Intercept & $4518.44 * *$ & 273.73 & 0.00 & 0.08 & -1.63 & 11.39 \\
\hline \multirow{7}{*}{$\begin{array}{l}\text { Exper- } \\
\text { ience }\end{array}$} & BEN & n.s. & & n.s. & & 0.05 & 8.12 \\
\hline & FISH & $32.41 * *$ & 12.34 & $11.39 * *$ & 14.3 & n.s. & \\
\hline & MAT & n.s. & & n.s. & & n.s. & \\
\hline & OCT & $-6.51 * *$ & 12.17 & n.s. & & n.s. & \\
\hline & RIVT & $5.17 *$ & 6.25 & $-3.10 * *$ & 7.37 & n.s. & \\
\hline & YEARS & n.s. & & $3.7 *$ & 5.29 & n.s. & \\
\hline & EDU & n.s. & & $30.60 * *$ & 20.54 & n.s. & \\
\hline \multirow[t]{3}{*}{ Enviro } & BORE & $-59.32 * *$ & 251.78 & n.s. & & & \\
\hline & PHOT & $801.30 * *$ & 51.65 & $220.16^{* *}$ & 19.18 & -0.62 & 28.41 \\
\hline & WEIGHT & n.s. & & n.s. & & 0.03 & 55.90 \\
\hline \multirow[t]{2}{*}{ Geo } & DISTHQ & n.s. & & n.s. & & 0.00 & 20.97 \\
\hline & AREAMA & n.s. & & n.s. & & 0.00 & 14.46 \\
\hline \multicolumn{8}{|l|}{ Tech } \\
\hline & BOAT & $-46.55 * *$ & 36.91 & n.s. & & n.s. & \\
\hline & $\mathrm{N}$ & 109 & & 75 & & 218 & \\
\hline & Unit of analysis & Fisher & & Fisher & & Fisher & \\
\hline
\end{tabular}

Note: $* *$ is highly significant where $\mathrm{p}<0.01, *$ is significant where $\mathrm{p}<0.05,+$ is slightly significant where $\mathrm{p}<0.1$, and $\mathrm{n} . \mathrm{s}$. is not significant.

Fig. 4. Percent variance in price explained by environmental and experience factors for the loco and congrio fisheries.

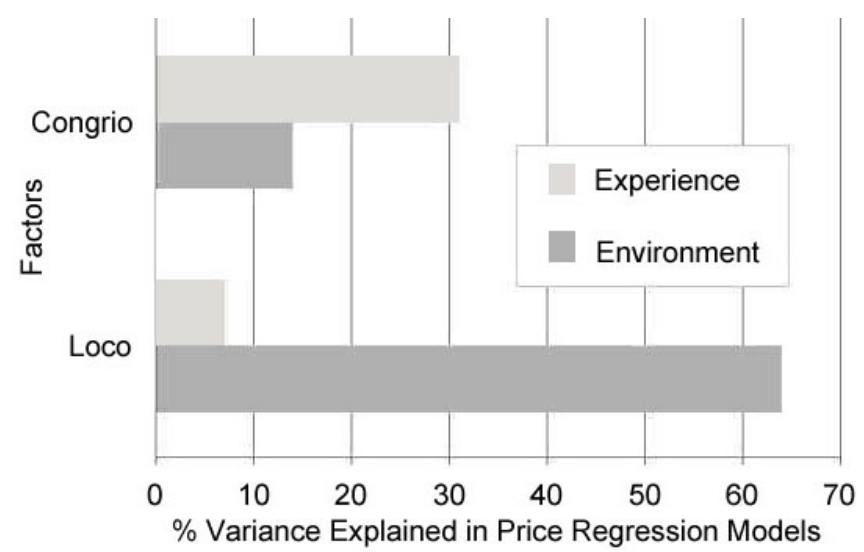

The discriminant analysis of successful ( $\geq$ median price) vs. non-successful (< median price) loco fishers was highly accurate for successful $(94.34 \%)$ and unsuccessful fishers $(83.05 \%)$ (Tables 6 and 7; Figure 3). The most successful fishers had management areas with high photosynthetic biomass, locos with fewer endobionts, and the heaviest loco meat. Fishers had an advantage if they lived farther away from the Valdivian market. Boat availability was not significant.

Fishers with the highest income from the management area (profit) worked in management areas with high photosynthetic biomass and heaviest loco meat (Table 5; Figure 3; Appendix 3). Fishers who worked in multiple benthic fisheries, likely the divers, got better prices for their locos. Fishers who worked in management areas that spanned across a greater area (larger $\mathrm{km}^{2}$ ) and lived close to the fisher headquarters made a higher monthly income from the management area. The discriminant analysis has similar findings; successful fishers worked in better environments, their locos had fewer endobionts, and they had larger management areas (Tables 6 and 7; Figure 3). Technology was contradictory to success in the discriminant analysis; fewer boats were better. Regarding experience, fishers who worked in multiple fishing activities (diving, purse seine fishery, and the small-scale open fishery) had an advantage, but the mean difference in successful and unsuccessful fishers was very small. Also distance to the headquarters had the opposite relationship when compared with the multiple regression analysis, but this variable explained a small fraction of success.

\section{Open-access congrio}

Chlorophyll-a concentration (environment) explained $13 \%$ of the price variation in congrio; fisher experience explained $16 \%$ 
Table 6. Partial r-square, significance levels, and average squared canonical correlation of stepwise discriminant analysis of loco characteristics. Successful and unsuccessful fisher groups were split using median values. In the discriminant analysis, independent variables entered and remained in the model if $p$-value $\leq 0.15$.

\begin{tabular}{|c|c|c|c|c|c|c|}
\hline Step & Variable & $\begin{array}{c}\text { Partial } \\
\text { R-Square }\end{array}$ & $\operatorname{Pr}>F$ & $\begin{array}{c}\text { Average squared } \\
\text { canonical } \\
\text { correlation }\end{array}$ & $\begin{array}{c}\text { Mean Values } \\
\text { Successful }\end{array}$ & $\begin{array}{l}\text { Mean Values } \\
\text { Unsuccessful }\end{array}$ \\
\hline \multicolumn{7}{|l|}{ Loco } \\
\hline 1 & WEIGH (g) & 0.43 & $<0.001$ & 0.44 & 126 & 104 \\
\hline 2 & BORE (\%) & 0.17 & $<0.001$ & 0.53 & 10 & 19 \\
\hline 3 & PHOT $\left(\mathrm{mg} / \mathrm{m}^{3}\right)$ & 0.15 & $<0.001$ & 0.65 & 2 & 2 \\
\hline 4 & $\operatorname{ROADV}\left(\mathrm{km}^{2}\right)$ & 0.10 & $<0.001$ & 0.68 & 96 & 49 \\
\hline 5 & $\operatorname{BEN}(\#)$ & 0.04 & 0.03 & 0.69 & 4 & 6 \\
\hline 6 & YEAR (y) & 0.03 & 0.07 & 0.70 & 23 & 23 \\
\hline \multicolumn{7}{|c|}{ Congrio } \\
\hline 1 & $\operatorname{ROADV}\left(\mathrm{km}^{2}\right)$ & 0.23 & $<0.001$ & 0.24 & 47 & 92 \\
\hline 2 & FAC (\#) & 0.05 & 0.05 & 0.28 & 1 & 2 \\
\hline 3 & AREAMA (ha) & 0.04 & 0.10 & 0.30 & 95 & 115 \\
\hline 4 & BOAT (\#) & 0.06 & 0.04 & 0.34 & 20 & 16 \\
\hline 5 & OAC (\#) & 0.07 & 0.02 & 0.39 & 1 & 2 \\
\hline 6 & BORE (\%) & 0.08 & 0.02 & 0.43 & 22 & 23 \\
\hline 7 & EDU (y) & 0.05 & 0.06 & 0.47 & 9 & 8 \\
\hline \multicolumn{7}{|c|}{ Management area } \\
\hline 1 & BORE (\%) & 0.16 & $<0.001$ & 0.16 & 13 & 25 \\
\hline 2 & AREAMA (ha) & 0.07 & $<0.001$ & 0.21 & 144 & 112 \\
\hline 3 & DISTHQ $\left(\mathrm{km}^{2}\right)$ & 0.05 & $<0.001$ & 0.25 & 1887 & 1418 \\
\hline 4 & FAC (\#) & 0.04 & $<0.001$ & 0.28 & 2 & 1 \\
\hline 5 & $\operatorname{BOAT}(\#)$ & 0.02 & 0.03 & 0.29 & 16 & 19 \\
\hline 6 & BEN (\#) & 0.04 & 0.01 & 0.32 & 6 & 6 \\
\hline
\end{tabular}

and formal education explained $11 \%$ (Tables 5; Figures 3 and 4; Appendix 3). Fishers who worked in multiple fin fisheries, spent many years fishing, and those who spent less time working in the rivers were most successful. More formal schooling also benefited price. Geospatial factors were not influential, nor were boats (technology).

The congrio model (Table 5) (using a base price of \$1.45) shows that experience was most influential in price, adding $\$ 0.02$ per $\mathrm{kg}$ for each additional species fished, $\$ 0.05$ per $\mathrm{kg}$ for each additional year spent in school, $\$ 0.01$ for each additional year fishing, and a loss of $\$ 0.05$ per $\mathrm{kg}$ for each additional $10 \%$ of a fisher's time that is dedicated to fishing in the river. An additional $0.2 \mathrm{mg} / \mathrm{m}^{3}$ increase in chlorophylla concentration in the management area added $\$ 0.03$ per kg.

The discriminant analysis (Tables 6 and 7; Figure 3 ) confirmed that experience counted for successful fishers; congrio fishers who included fewer activities outside of the fisheries and those who worked in fewer different fisheries (purse seine, finfish, and diving) were paid higher prices for congrio. Successful fishers had a slightly higher formal education. Successful fishers also had more boat power. A geospatial factor, proximity to the market, however, was the most influential since fishers located closer to the Valdivian market were more successful. Also fishers working in smaller management areas benefitted. The model predicted successful fishers with $81.25 \%$ and unsuccessful fishers with $88.57 \%$ accuracy (Tables 6 and 7).

Fishers are allocating their time and efforts in relation to the environment. In the management areas with higher photosynthetic biomass, fishers harvested fewer benthic species $(r=-0.38, p<0.001)$ and they spent a lower proportion of their time diving in the rivers $(\mathrm{r}=-0.42, \mathrm{p}<0.001)$. In management areas with high photosynthetic biomass and locos with many endobionts, fishers spend a larger proportion of time in the open ocean $(r=0.15, p=0.15$, PHOT; $r=0.2975$, $\mathrm{p}<0.001$, BORE). The fishers still spend a large fraction of their time working in the management areas $(r=0.16, p=0.09$, PHOT; $r=-0.2007, p=0.013$, BORE) probably because of the potential economic benefits.

\section{DISCUSSION}

\section{Landscape and management influences on strategies for success}

Success (price and profit) in the loco fishery depended mainly on the environmental influences of landscape change in the management area. Fishers had little control over the nutrient 
Table 7. Number of observations and percent classified and error count estimates of successful and unsuccessful groups using stepwise discriminant analysis.

\begin{tabular}{|c|c|c|c|c|}
\hline & & Successful & Unsuccessful & Total \\
\hline \multicolumn{5}{|c|}{ Loco } \\
\hline & \multirow[t]{2}{*}{ Successful } & 50 & 3 & 53 \\
\hline & & 94 & 66 & 100 \\
\hline & \multirow[t]{2}{*}{ Unsuccessful } & 10 & 49 & 59 \\
\hline & & 17 & 83.05 & 100 \\
\hline & \multirow[t]{2}{*}{ Total } & 60 & 52 & 112 \\
\hline & & 54 & 46.43 & 100 \\
\hline & Rate & 0.06 & 0.17 & 0.11 \\
\hline & Priors & 0.50 & 0.50 & \\
\hline \multicolumn{5}{|c|}{ Congrio } \\
\hline & \multirow[t]{2}{*}{ Successful } & 39 & 9 & 48 \\
\hline & & 81 & 19 & 100 \\
\hline & \multirow[t]{2}{*}{ Unsuccessful } & 4 & 31 & 35 \\
\hline & & 11 & 89 & 100 \\
\hline & \multirow[t]{2}{*}{ Total } & 43 & 40 & 83 \\
\hline & & 52 & 48 & 100 \\
\hline & Rate & 0.19 & 0.11 & 0.15 \\
\hline & Priors & 0.50 & 0.50 & \\
\hline \multicolumn{5}{|c|}{ Management Area } \\
\hline & \multirow[t]{2}{*}{ Successful } & 93 & 27 & 120 \\
\hline & & 77.5 & 23 & 100. \\
\hline & \multirow[t]{2}{*}{ Unsuccessful } & 55 & 79 & 134 \\
\hline & & 41.04 & 59 & 100 \\
\hline & \multirow[t]{2}{*}{ Total } & 148 & 106 & 254 \\
\hline & & 58.27 & 42 & 100 \\
\hline & Rate & 0.23 & 0.41 & 0.32 \\
\hline & Priors & 0.50 & 0.50 & \\
\hline
\end{tabular}

additions to their management areas from tree plantation development and if a fisher had a management area with good quality locos, then he/she was successful. If they had an area that was affected by landscape change, then they were not successful. The effect was dramatic with almost a $17 \%$ decrease in price for each $10 \%$ increase in endobionts. In the congrio fishery, however, environment was of little importance.

Management regulations, such as providing exclusive access, are creating some fisheries where anyone can profit regardless of skill or where skill cannot help fishers profit when spatially dependent environmental factors become large predictors of success. Experience does not foster success in the loco fishery. Fisher experience is relevant when fishers are seeking higher prices for open-access congrio fisheries and when explaining variation in loco fishery catches (CPUE and total catch). Indeed experience can help catch more locos, but this does not translate into higher prices or more profit for fishers. When success is measured by price, in the closed-access loco fishery, environment overwhelmingly predicts success and experience is of minimal influence. For congrio, however, the prices fishers receive for congrio benefits from fisher experience. The congrio fishery is not highly commercialized and it is the expert fishers who can capture enough fish so it is of interest to local buyers. Others harvest congrio at subsistence levels. To foster success in the congrio fishery, targeted programs that enhance fisher experience (skills and knowledge) could provide fishers with strategies to adapt. In the loco fishery, however, such a program would have little influence on success. In terms of the skipper effect studies, it may not be whether experience counts for fishers or not but when experience does and does not count. The environmental influence combined with fisheries regulations, providing exclusive access to fisheries, could be the mechanism that explains when experience counts.

Technology measures show that distinct fishing strategies are necessary for congrio and loco. While fishers with bigger fleets (\# of boats) did catch more locos, having larger fleets did not translate into financial benefits. Larger fleets were detrimental to financial success in the loco fishery (price $/ \mathrm{kg}$ and monthly management area income), whereas fleet size fostered financial success in the congrio fishery. Larger fleets 
help make sure that fishers harvest entire quotas, which usually means fishers extract small locos and this likely affects price and profit. Investing in more technology for locos is not financially wise. Technology advances would be more likely to help fishers succeed in offshore fisheries. Our findings agree with skipper effect studies in that technology had some positive influences on success (congrio price and loco catch per unit effort) (Palsson and Durrenburger 1982, Hilborn and Ledbetter 1985, Thorlindsson 1988) but more catch does not always translate into more money.

Geospatial factors are probably picking up on the environmental factors since locos farthest from the market also tend to have fewer landscape change influences. Geospatial factors outweigh the experience effect for loco catch per unit effort and profit measures (monthly income from the management area). In the CPUE data, distance to the MA was most influential on price, so those fishers located further away from their MA, but closest to the market were more successful. The profit measure shows that larger MAs and those fishers who live far from the fishing headquarters are more successful.

\section{Fisher response to environmental change and fisheries management}

Fishers cannot easily change fishing strategies within the closed-access loco fishery to succeed if their management areas contain locos with many endobionts. Fisher experience and technology cannot help them overcome the financial influences of the endobionts on loco shellfish. Some experienced fishers who work in management areas with poor quality resources are depending less on the loco fishery and working in offshore fisheries such as congrio or sierra (Thyrsites atun), or river fisheries such as choro zapato (Choromytilus chorus) and chorito (Mytilus chilensis) where their experience counts. Offshore fisheries likely expose fishers to more risk (financial and safety). Our survey shows that fishers in Mehuin, a fishing village where many fishers work in management areas with high levels of endobionts on locos are adapting to these changes by switching to offshore species. Other fishers in the Mehuin region are giving up fishing, in part because the Celco Arauco tree plantation company has offered some fishers financial incentives to limit their protests about environmental issues associated with their pulp mill (Van Holt, personal observation). As a consequence, novice and expert fishers are in conflict. Loco is the main moneymaking resource and novice fishers have sometimes squeezed the more experienced fishers out of the fishery because they were allocated better quality management areas (further from tree plantations) when the regions were first established.

New fishers with good quality management areas are also vulnerable if their loco resources decline because these fishers are not developing the experience that will help them succeed offshore in the congrio and other fisheries. Since success in loco fisheries does not depend on experience, the traditional ecological knowledge and skills that will help fishers adapt to fish offshore are likely not being learned. Another syndicate outside of this research area typically had good quality resources (no endobionts). However, in 2004, they harvested locos with a low weight given their shell length (Van Holt 2009). These part-time fishers did not participate in offshore fisheries since they focus their efforts on other livelihood activities. This allowed them to maintain fishing the following year. But as these new fishers such as these get drawn into economic benefits of the loco fishery and dedicate themselves exclusively to that fishery, they will lose their ability to engage in alternative livelihoods that enable them to hold on until the next year when the quality (hopefully) improves. These types of fishers need to improve their fishing skills, experience, and traditional ecological knowledge or they may not be able to switch to different fisheries as some fishers in the Mehuin region did.

For adaptation, the social-ecological system should foster the capacity for learning (Folke 2006). To foster adaptation to the effects of landscape change, management activities could (1) foster traditional ecological knowledge, (2) expand management areas, (3) reduce the effects of landscape change and, (4) develop onshore livelihood activities.

To foster traditional ecological knowledge and experience, fishers should continue to develop their offshore fishing skills. A recent fishing net diversification program supported by the Chilean Government in the Valdivia Province is an example of a program that could help cultivate new strategies for success and prepare fishers to respond to environmental change. Fishers were given different sized fishing nets to diversify catches. Based on this study, fishers working in the congrio would immediately benefit and those working in loco would gain a smaller immediate benefit. Becoming skilled in diverse fishing strategies could prove useful for novice fishers as well if the environmental condition in management areas degrades, because the fishers trained in using other gear types will begin to develop skills that can help them harvest other open access resources that are not as influenced by landscape change and require more experience to catch. Since it is likely that fishers working in the congrio fishery are exposing themselves to more risk, training programs should incorporate ways to minimize risk, whether it be managing the nets, fishing and navigational strategies, or marketing approaches. Of course offshore fisheries have been overharvested in the past, but there appear to be viable fishing opportunities along the Chilean coast for artisanal fishers.

The Chilean government could expand the TURF management system so fishers can become more resilient to environmental variation. In systems governed from the bottom up, changing rules are part of the adaptive process (Ostrom 1999). The TURF management system introduces rigidity into the system because fishers cannot move to other locations to catch benthic resources legally. Basurto (2008) found that 
fisher success and conservation depended on fishers harvesting from a suite of regions, which either consciously or serendipitously allowed them to harvest resources that demanded higher prices while conserving the species for future harvest. Integrating flexibility into the Chilean system may help fishers use their own strategies to respond to change and succeed, gaining higher prices for their resources, and producing incentives to reduce illegal catches (Gonzalez et al. 2006). One way to introduce flexibility is to allow fishers to harvest multiple areas.

Of course conservation efforts should focus on mitigating the nutrient inputs into the system. Scientists have reported effective recovery from eutrophication if limits are placed on nutrient inputs (Ruhl and Rybicki 2010). Research on the enrichment effects of area and percent watershed covered by tree plantations and harvesting rotation patterns could provide practical information to mitigate the nutrient input into the coastal system. Limits on the slope where plantations are established, the amount of riparian vegetation present, and the nutrient input on plantations could also help. Currently the Valdivian province is developing a regional coastal management plan to integrate land-sea interactions. This type of planning may offer a novel approach to limit nutrient inputs and foster fisher success.

Finally, success in fisheries can depend in part on the ability of fishers to weather the challenges faced when prices decline for certain resources. To level the playing field in Chile, experienced fishers should also be given opportunities for land-based livelihoods and land. Future research should identify what alternative land-based livelihoods could best capitalize on fisher experience and skills.

\section{CONCLUSION}

Experience and technology limit success when fishers are restricted to harvest in specific locations and environmental conditions are distinct and affect resource quality in management areas. Regulations that spatially and temporally limit how fishers fish could be an important trigger that alter the conditions for success, specifically when experience and technology do and do not explain success. Environmental features, which stemmed from landscape change, best explained price differences for the benthic, closed-access, loco fisheries because these organisms are relatively stationary compared to finfish and are directly influenced by landscape change. Experience and technology, which help fishers catch more fish and perhaps find the better resources, does not compensate for the influence of landscape change in these fisheries. Those fishers in management areas with poor quality resources are vulnerable to environmental change because the traditional means by which fishers adapt to change (experience and technology) do not foster success.

Experience explained a smaller fraction of success for the loco fishery and a larger fraction of success for the congrio fishery. Diving experience helped loco fishers succeed and offshore fishery experience helped the congrio fishers succeed. Only in the open-access fisheries was fisher experience powerful enough and the influence of the environment low enough that fishers could adapt to succeed in a region affected by landscape change. Fishers working offshore may be exposed to more risk and management strategies could be developed to help fishers mitigate risk in these new offshore fisheries.

Might we be inadvertently suppressing traditional ecological knowledge by closing access to harvesting areas? Does this leave fishers more vulnerable to environmental change? Is there an optimal-sized management area that can encompass both benthic and finfish species, allowing for success and fostering traditional ecological knowledge? Could fisheries that showed no observed (etic) evidence of a skipper effect evolve to have one and vice versa if the environmental condition or regulations change the way that people fish and the ease with which people can harvest resources? Comparing success across cases where traditional fisher success measures (experience and technology) combined with geospatial and environmental characteristics of harvest areas in closed- and open-access systems can help us answer these questions and to continue to build mechanistic understanding of success to foster adaptation in dynamic environments.

Responses to this article can be read online at: http://www.ecologyandsociety.org/voll7/iss1/art28/ responses/

\section{Acknowledgments:}

I thank H. Russell Bernard, Michael Binford, Kenneth Portier, Carlos Moreno, Sandor Mulsow, and Tom Frazer for their advice on this interdisciplinary research design and extensive comments on the manuscript. Xavier Basurto, David Griffith, Jeffrey C. Johnson, Philip Adams, and anonymous reviewers offered valuable comments, greatly improving the quality of this manuscript. I am grateful to the fishers of FIPASUR, the president Marco Ida and Tito Gomez and Gaston Toro, who represented the fishers in the Mehuin region. Magdalena Alid (Proyecto Asociativo de Fomento Cerqueros de Valdivia), Leny Cares, and Sandro Araneda helped to develop locally relevant questionnaires and administer the survey. I thank the Ecology and Evolution, Geosciences, and Forestry Department at Universidad Austral. I also thank the many undergraduate students who helped with the survey instrument and Juan Paulo Torres and Sandra Cuellar who assisted in analysis of loco health. Guillermo Quiroz, formerly the fisheries director in SERNAPESCA, provided catch data. Rodrigo Vergara assisted with statistical analyses and field work. This work was supported by NASA Earth System Science Fellowship (ESSF/04R-0000-0080), as well as the David Boren Fellowship, Rotary Ambassadorial Scholarship Program, Explorer's Club, the Tropical Conservation and Development Program, the Geography Department, School of 
Natural Resources and Environment, and the Land Use and Environmental Change Institute of the University of Florida. IRB approval (03031304) was obtained at the University of Florida.

\section{LITERATURE CITED}

Acheson, J. M. 1977. Technical skills and fishing success in the Maine lobster industry. Human Ecology 3:183-207.

Acker, J. G., and G. Leptoukh. 2007. Online analysis enhances use of NASA earth science data. Eos, Transactions, American Geophysical Union 88(2):14-17.

Aswani, S. 1998. Patterns of marine harvest effort in southwestern New Georgia, Solomon Islands: resource management or optimal foraging? Ocean and Coastal Management 40:207-235. http://dx.doi.org/10.1016/S0964-5691 (98)00047-7

Aswani, S. 1999. Common property models of sea tenure: a case study from Roviana and Vonavona Lagoons, New Georgia, Solomon Islands. Human Ecology 27(3):417-453. http://dx.doi.org/10.1023/A:1018727607651

Auty, R. M. 1993. Sustaining development in mineral economies: the resource curse thesis. Routledge, London, UK.

Basurto, X. 2008. Biological and ecological mechanisms supporting marine self-governance: the Seri Callo de Hacha fishery in Mexico. Ecology and Society 13(2):20. http://www. ecologyandsociety.org/vol13/iss2/art20/

Berkes, F., J. Colding, and C. Folke. 2000. Rediscovery of traditional ecological knowledge as adaptive management. Ecological Applications 10:1251-1262. http://dx.doi.org/10.1 890/1051-0761(2000)010[1251:ROTEKA]2.0.CO;2

Bernal, P. A., D. Oliva, B. Aliaga, and C. Morales. 1999. New regulations in Chilean fisheries and aquaculture: ITQs and territorial users rights. Ocean and Coastal Management 42:119-142. http://dx.doi.org/10.1016/S0964-5691(98)00049-0

Bernard, H.R. 1967 Kalymnian sponge diving. Human Biology 39:103-130.

Bjarnason, T., and T .Thorlindsson. 1993. In defense of a folk model: the "skipper effect" in the Icelandic cod fishery. American Anthropologist 95 (2):371-94. http://dx.doi.org/10. $\underline{1525 / \mathrm{aa} .1993 .95 .2 .02 \mathrm{a} 00060}$

Canales, D., L. Caballero, and A. Aranís. 2008. Catch per unit effort of Chilean jack mackerel (Trachurus murphyi) of the purse seine fishery off south-central Chile $\left(32^{\circ} 10^{\prime}-40^{\circ} 10^{\prime}\right.$ S) 1981-2005. Chilean Jack Mackerel Workshop. June 30-July 4, 2009. South Pacific Regional Fisheries Management Organization (SPRFMO) and the Sub-Secretaría de Pesca, Chile.
Chong, J., K. Sepulveda, and C. M. Ibanez. 2006. Variación temporal en la dieta del congrio Colorado, Genypterus chilensis (Guichenot, 1881) frente al literal de Talcahuano, Chile (36 32'S - 36 45'S). Revista de Biologia Marina y Oceanografia 41(2):195-202. http://dx.doi.org/10.4067/S071 8-19572006000200007

Cinner, J. E., and T. R. McClanahan. 2006. Socioeconomic factors that lead to overfishing in coral reef fisheries of Papua New Guinea. Environmental Conservation 33(1):73-80. http: //dx.doi.org/10.1017/S0376892906002748

Cohen, J. E., C. Small, A. Mellinger, J. Gallup, J. Sachs, P. M. Vitousek, and H. A. Mooney. 2007. Estimates of coastal populations. Science 278(5341):1121.

Diaz, R. J., and R. Rosenberg. 1995. Marine benthic hypoxia: a review of its ecological effects and the behavioral responses of benthic macrofauna. Oceanography and Marine Biology 33:245-303.

Durrenberger, E. P. 1993. The skipper effect and folk models of the skipper effect among Mississippi shrimpers. Human Organization 52:194-202.

Durrenberger, E. P. 1996. Gulf Coast surroundings: people and policy in the Mississippi shrimp industry. University Press of Kansas. Lawrence, Kansas, USA.

FAO (Food and Agriculture Organization). 2010. The state of world fisheries and aquaculture 2010. FAO Fisheries and Aquaculture Department, Food and Agriculture Organization of the United Nations, Rome, Italy.

Folke, C. 2006. Resilience: the emergence of a perspective for social-ecological systems analyses. Global Environmental Change 16:253-267. http://dx.doi.org/10.1016/j.gloenvcha.20 $\underline{06.04 .002}$

Gelcich, S., G. Eduards-Jones, M. J. Kaiser, and J. C. Castilla. 2006. Co-management policy can reduce resilience in traditionally managed marine ecosystems. Ecosystems 9 (6):951-966. http://dx.doi.org/10.1007/s10021-005-0007-8

Gelcich, S., G. Edwards-Jones, and M. J. Kaiser. 2007. Heterogeneity in fishers' harvesting decisions under a marine territorial user rights policy. Ecological Economics 61:246-254. http://dx.doi.org/10.1016/j.ecolecon.2006.02.017

Gelcich, S., T. P. Hughes, P. Olsson, C. Folke, O. Defeo, M. Fernandez, S. Foale, L. Gunderson, C. Rodrigues-Sikert, M. Scheffer, R. S. Steneck, and J. C. Castilla. 2010. Navigating transformations in governance of Chilean marine coastal resources. Proceedings of the National Academy of Sciences 107 16794-16799. http://dx.doi.org/10.1073/pnas.1012021107 
Gonzalez, J., W. Stotz, J. Garrido, J. M. Orensanz, A. M. Parma, C. Tapia, and A. Zuleta. 2006. The Chilean turf system: how is it performing in the case of the loco fishery? Bulletin of Marine Science 78(3):499-527.

Guest, G. 2003. Fishing behavior and decision-making in an Ecuadorian community: a scaled approach. Human Ecology 31(4):611-644. http://dx.doi.org/10.1023/B:HUEC.00000055 $\underline{16.70903 .18}$

Guerra, E., M. A. Herrera, and F. Drake. 2007. Profitability of fertilization at establishment of Eucalyptus globules plantations. Agrociencia 41(7):797-804.

Gwynne, R. N. 1996. Direct foreign investment and nontraditional export growth in Chile: the case of the forestry sector. Bulletin of Latin American Research 15(3):341-357. http://dx.doi.org/10.1016/0261-3050(96)00005-8

Hilborn, R., and M. Ledbetter. 1985. Determinants of catching power in the British Columbia salmon purse seine fleet. Canadian Journal of Fisheries and Aquatic Sciences 56:394-406.

Johnson, J. C., and M. K. Orbach. 1990. A fishery in transition: the impact of urbanization on Florida's spiny lobster fishery. City and Society 4(1):88-104. http://dx.doi.org/10.1525/city.1 990.4.1.88

Kemp, W. M., W. R. Boynton, J. E. Adolf, D. F. Boesch, W. C. Boicourt, G. Brush, J. C. Cornwell, T. R. Fisher, P. M. Glibert, J. D. Hagy, L. W. Harding, E. D. Houde, D. G. Kimmel, W. D. Miller, R. I. E. Newell, M. R. Roman, E. M. Smith, and J. C. Stevenson. 2005. Eutrophication of Chesapeake Bay: historical trends and ecological interactions. Marine Ecology-Progress Series 303:1-29. http://dx.doi.org/1 0.3354/meps303001

Lara, A., and T. Veblen. 1993. Forest plantations in Chile: a successful model? Pages 118-139 in A. Mather, editor. Afforestation: policies, planning, and progress. Belhaven Press, UK.

Little, C., D. Soto, A. Lara, and J. G. Cuevas. 2008. Nitrogen exports at multiple-scales in a southern Chilean watershed (Patagonian Lakes district). Biogeochemistry 87:297-309. http://dx.doi.org/10.1007/s10533-008-9185-8

Mallows, C. L. 1973. Some comments on Cp. Technometrics 15:661-675. http://dx.doi.org/10.2307/1267380

Nixon, S.W. 1995. Coastal marine eutrophication: a definition, social causes, and future concerns. Ophelia 41:199-219.

Ostrom, E. 1999. Coping with tragedies of the commons. Annual Review of Political Science 2:493-535. http://dx.doi.o $\mathrm{rg} / 10.1146 /$ annurev.polisci.2.1.493

Oyarzun, C., C. Aracena, P. Rutherford, R. Godoy, and A. Deschrijver. 2007. Effects of land use conversion from native forest to exotic plantations on nitrogen and phosphorus retention in catchments of southern Chile. Water Air Soil Pollution 179:341-350. http://dx.doi.org/10.1007/s11270-006 $-9237-4$

Palsson, G., and P. Durrenberger. 1982. To dream of fish - the causes of Icelandic skippers' fishing success. Journal of Anthropological Research 38:227-242.

Palsson, G., and E. P. Durrenberger. 1990. Systems of production and social discourse-the skipper effect revisited. American Anthropologist 92:130-141. http://dx.doi.org/10.1525/ $\underline{\text { aa.1990.92.1.02a00090 }}$

Ruhl, H. A., and N. B. Rybicki. 2010. Long-term reductions in anthropogenic nutrients link to improvements in Chesapeake Bay habitat. Proceedings of the National Academy of Sciences 107(38):16566-16570. http://dx.doi.org /10.1073/pnas.1003590107

Russell, S. D., and R. T. Alexander. 1996. The skipper effect debate: views from a Philippine Fishery. Journal of Anthropological Research 52:433-459.

Salas, S., and D. Gaertner. 2004. The behavioural dynamics of fishers: management implications. Fish and Fisheries 5:153-167. http://dx.doi.org/10.1111/j.1467-2979.2004.00146. $\mathrm{x}$

Sampson, D. B. 1994. Fishing tactics in a 2-species fisheries model- the bioeconomics of bycatch and discarding. Canadian Journal of Fisheries and Aquatic Sciences 51(12):2688-2694.

SAS. 2001. SAS/STAT. SAS Institute Inc., Cary, North Carolina, USA.

Schlatter, J. E. 1977. La relación entre suelo y plantaciones de Pinus radiata D. Don en Chile Central: Análisis de la situación actual y planteamientos para su futuro manejo. Bosque 2 (1):12-31.

Sedjo, R. A. 1999. The potential of high-yield plantation forestry for meeting timber needs. New Forests 17: 339-359. http://dx.doi.org/10.1023/A:1006563420947

Servicio Nacional de Pesca (SERNAP). 2003. Anuarios Estadisticos 2003. Servicio National de Pesca, Ministerio de Economia, Fomento y Reconstruccion Chile, Valparaiso, Chile.

Servicio Nacional de Pesca (SERNAP). 2004. Anuario estadistico de pesca 2004. Servicio National de Pesca, Ministerio de Economia, Fomento y Reconstruccion Chile, Valparaiso, Chile.

Servicio Nacional de Pesca (SERNAP). 2005. Anuario estadistico de pesca 2005. Servicio National de Pesca, Ministerio de Economia, Fomento y Reconstruccion Chile, Valparaiso, Chile. 
Shester, G. G. 2010. Explaining catch variation among Baja California lobster fishers through spatial analysis of trapplacement decisions. Bulletin of Marine Science 86 (2):479-498.

Smith, V. H., G. D. Tilman, and J. C. Nekola. 1999. Eutrophication: impacts of excess nutrient inputs in freshwater, marine, and terrestrial ecosystems. Environmental Pollution 100:179-196. http://dx.doi.org/10.1016/S0269-7491 (99)00091-3

Spiegelhalter, D. J., N. G. Best, B. P. Carlin, and A. van der Linde. 2002. Bayesian measures of model complexity and fit (With discussion). Journal of the Royal Statistical Society: Series B 64:583-639. http://dx.doi.org/10.1111/1467-9868.00353

Thorlindsson, T. 1988. The skipper effect in the Icelandic herring fishery. Human Organization 47(3):199-212.

Van Holt, T. 2009. Influence of twenty years of land use/land cover change on the Concholepas concholepas (loco or Chilean abalone) fisheries and consequences for fishers. Dissertation. University of Florida, Gainesville, USA.

Van Holt, T., C. A. Moreno, M. W. Binford, K. M. Portier, S. Mulsow, and T. K. Frazer. 2012. Influence of landscape change on nearshore fisheries in southern Chile. Global Change Biology, in press. http://dx.doi.org/10.1111/j.1365-24 $\underline{\text { 86.2012.02674.x }}$

Verity, P. G., and V. Smetacek. 1996. Organism life cycles, predation, and the structure of marine pelagic ecosystems. Marine Ecology Progress Series 130:277-293. http://dx.doi.o $\mathrm{rg} / 10.3354 / \mathrm{meps} 130277$

Ware, D. M., and R. E. Thomson 2005. Bottom-up ecosystem trophic dynamics determine fish production in the Northeast Pacific. Science 308(5726):1280 -1284. http://dx.doi.org/10.1 $\underline{126 / \text { science. } 1109049}$

Zander, C. D., and L. W. Reimer. 2002. Parasitism at the ecosystem level in the Baltic Sea. Parasitology 124:S119S135. http://dx.doi.org/10.1017/S0031182002001567 
APPENDIX 1. Descriptive statistics for variables used for the loco, congrio, and management area income analysis where fisher is the unit of analysis.

\begin{tabular}{lrrrrr}
\hline Variable & $\mathrm{N}$ & Mean & Std Dev & Minimum & Maximum \\
\hline PLANT $\left(\mathrm{km}^{2}\right)$ & 279 & 896.0 & 566.5 & 27.1 & 1264.0 \\
ROADV $(\mathrm{km})$ & 279 & 68.4 & 45.9 & 17.9 & 152.9 \\
PHOT $\left(\mathrm{mg} / \mathrm{m}^{3}\right)$ & 279 & 2.1 & 0.5 & 1.2 & 2.7 \\
BORE (\%) & 255 & 19.2 & 15.5 & 3.7 & 42.6 \\
WEIGHT (g) & 255 & 112.1 & 16.2 & 88.4 & 134.8 \\
BOAT (\#) & 279 & 17.8 & 6.8 & 7.0 & 28.0 \\
EDU (y) & 277 & 9.0 & 3.1 & 0.1 & 17.0 \\
YEAR (y) & 244 & 24.7 & 12.1 & 1.0 & 63.0 \\
DISTHQ (m) & 278 & 1622.1 & 3057.9 & 0.0 & 25000.0 \\
AREAAM (ha) & 279 & 126.1 & 65.4 & 49.0 & 352.0 \\
MAT (\%) & 279 & 35.7 & 25.7 & 0.0 & 100.0 \\
OCT (\%) & 279 & 49.7 & 31.4 & 0.0 & 100.0 \\
RIVT (\%) & 279 & 18.0 & 27.8 & 0.0 & 100.0 \\
FISH (\#) & 279 & 7.8 & 5.9 & 0.0 & 23.0 \\
BEN (\#) & 279 & 5.8 & 3.6 & 0.0 & 14.0 \\
Loco (\$/kg) & 142 & 4787.0 & 863.8 & 3000.0 & 6000.0 \\
Congrio (\$/kg) & 92 & 947.3 & 172.0 & 400.0 & 1300.0 \\
MAI (rank order) & 279 & 1.4 & 0.9 & 0.0 & 4.0 \\
TOTAL (\#) & 279 & 64659.3 & 60331.2 & 3723.0 & 262703.0 \\
CPUE (catch/day) & 279 & 16395.5 & 11206.7 & 3016.0 & 39633.0 \\
\hline
\end{tabular}

Note for MAI, monthly management area income (UD\$/month):

1: $<\$ 50$

2: $\$ 50$ - $\$ 99$

3: $\$ 100$ - \$149

4: $\$ 150$ - \$200 
APPENDIX 2. Descriptive statistics for variables used for the loco, congrio, and management area income analysis where fishing syndicate is the unit of analysis.

\begin{tabular}{lrrrrr}
\hline Variable & $\mathrm{N}$ & Mean & Std Dev & Minimum & Maximum \\
\hline PLANT $\left(\mathrm{km}^{2}\right)$ & 11 & 926.7 & 577.8 & 27.1 & 1264.0 \\
ROADV $(\mathrm{km})$ & 11 & 70.6 & 48.2 & 17.9 & 152.9 \\
PHOT $\left(\mathrm{mg} / \mathrm{m}^{3}\right)$ & 11 & 2.3 & 0.5 & 1.2 & 2.7 \\
BORE $(\%)$ & 11 & 21.5 & 16.4 & 3.7 & 42.6 \\
WEIGHT (g) & 11 & 114.1 & 16.2 & 88.4 & 134.8 \\
BOAT (\#) & 11 & 16.2 & 6.6 & 7.0 & 26.0 \\
EDU (y) & 11 & 8.9 & 0.9 & 7.2 & 10.2 \\
YEAR (y) & 11 & 24.6 & 3.7 & 18.5 & 31.1 \\
DISTHQ (m) & 11 & 1806.8 & 1388.4 & 353.1 & 4200.0 \\
AREAAM (ha) & 11 & 134.9 & 78.6 & 70.0 & 352.0 \\
MAT (\%) & 11 & 36.3 & 14.2 & 17.8 & 62.0 \\
OCT (\%) & 11 & 51.2 & 17.2 & 27.3 & 79.9 \\
RIVT (\%) & 11 & 15.9 & 18.0 & 0.0 & 52.8 \\
FISH (\#) & 11 & 8.4 & 3.2 & 4.9 & 16.4 \\
BEN (\#) & 11 & 5.5 & 1.8 & 2.7 & 9.1 \\
Loco (\$/kg) & 11 & 4362.9 & 953.5 & 3000.0 & 5800.0 \\
Congrio (\$/kg) & 11 & 922.7 & 133.3 & 700.0 & 1133.3 \\
MAI (rank order) & 11 & 1.4 & 0.5 & 0.4 & 2.1 \\
TOTAL (\#) & 11 & 71261.6 & 73860.1 & 3723.0 & 262703.0 \\
CPUE (\#/day) & 11 & 13774.4 & 10480.1 & 3016.0 & 39633.0 \\
\hline
\end{tabular}


APPENDIX 3. The best models for each number of variables with $\mathrm{R}^{2}$, Adjusted $\mathrm{R}^{2}, \mathrm{C}(\mathrm{p})$, AIC, $\mathrm{BIC}$, and the explanatory variables. Percent variation explained by each factor was calculated by comparing $\mathrm{R}^{2}$ values.

\begin{tabular}{|c|c|c|c|c|c|c|}
\hline & Variables in Model & $\mathrm{R}^{2}$ & Adj. $\mathrm{R}^{2}$ & $C(p)$ & AIC & $\mathrm{BIC}$ \\
\hline \multirow[t]{9}{*}{ Loco Price } & BORE & 0.43 & 0.43 & 149.72 & 1413.80 & 1412.85 \\
\hline & PHOT BORE & 0.64 & 0.64 & 58.24 & 1365.95 & 1365.80 \\
\hline & PHOT BORE BOAT & 0.70 & 0.69 & 35.27 & 1349.61 & 1349.93 \\
\hline & PHOT BORE BOAT RIVT & 0.71 & 0.70 & 30.65 & 1346.18 & 1346.54 \\
\hline & PHOT BORE BOAT OCT FISH & 0.74 & 0.72 & 21.57 & 1338.44 & 1339.46 \\
\hline & $\begin{array}{l}\text { PHOT BORE BOAT OCT RIVT } \\
\text { FISH }\end{array}$ & 0.75 & 0.74 & 16.72 & 1333.96 & 1335.62 \\
\hline & $\begin{array}{l}\text { PHOT BORE BOAT YEARS } \\
\text { OCT RIVT FISH }\end{array}$ & 0.76 & 0.75 & 14.27 & 1331.53 & 1333.79 \\
\hline & PHOT BORE BOAT AGE & 0.77 & 0.75 & 13.19 & 1330.36 & 1333.18 \\
\hline & YEARS OCT RIVT FISH & & & & & \\
\hline \multirow{5}{*}{$\begin{array}{c}\text { Congrio } \\
\text { Price }\end{array}$} & PHOT & 0.14 & 0.13 & 35.35 & 777.55 & 778.22 \\
\hline & PHOT FISH & 0.23 & 0.20 & 26.38 & 771.50 & 772.14 \\
\hline & PHOT EDU FISH & 0.34 & 0.31 & 14.12 & 761.72 & 762.72 \\
\hline & PHOT EDU RIVT FISH & 0.40 & 0.36 & 9.10 & 756.54 & 758.66 \\
\hline & PHOT EDU YEARS RIVT FISH & 0.45 & 0.40 & 6.00 & 753.20 & 756.21 \\
\hline Monthly & DISTHQ & 0.08 & 0.07 & 87.0 & -69.50 & -68.75 \\
\hline Management & PHOT WEIGH & 0.16 & 0.15 & 61.74 & -88.23 & -87.53 \\
\hline \multirow[t]{5}{*}{ Area Income } & PHOT WEIGH DISTHQ & 0.23 & 0.22 & 40.78 & -105.33 & -104.41 \\
\hline & PHOT WEIGH DISTHQ & 0.29 & 0.27 & 24.81 & -119.53 & -118.18 \\
\hline & AREAMA & & & & & \\
\hline & PHOT WEIGH DISTHQ & 0.33 & 0.31 & 12.13 & -131.74 & -129.74 \\
\hline & AREAMA BEN & & & & & \\
\hline CPU & DISTMA & 0.64 & 0.60 & 3.39 & 194.06 & 196.29 \\
\hline geospatial & DISTMA ROADV & 0.75 & 0.69 & 2.18 & 192.00 & 196.62 \\
\hline $\begin{array}{c}\text { CPU } \\
\text { environment }\end{array}$ & PHOT & 0.50 & 0.45 & 0.98 & 198.91 & 202.13 \\
\hline \multirow{3}{*}{$\begin{array}{l}\text { Total Catch } \\
\text { experience }\end{array}$} & RIVT & 0.27 & 0.19 & 22.10 & 246.15 & 244.89 \\
\hline & MAT RIVT & 0.46 & 0.32 & 16.55 & 244.85 & 243.43 \\
\hline & OCT MAT RIVT & 0.82 & 0.75 & 4.00 & 234.48 & 240.40 \\
\hline \multirow{3}{*}{$\begin{array}{c}\text { CPU } \\
\text { experience }\end{array}$} & RIVT & 0.70 & 0.67 & 11.20 & 192.14 & 192.24 \\
\hline & BOAT OCT & 0.81 & 0.76 & 6.55 & 189.14 & 190.85 \\
\hline & BOAT OCT RIVT & 0.88 & 0.83 & 4.00 & 185.63 & 191.54 \\
\hline
\end{tabular}

